De Jure: Jurnal Hukum dan Syar'iah

Vol. 12, No. 2, 2020, h. 214-226

ISSN (Print): 2085-1618, ISSN (Online): 2528-1658

DOI: http://dx.doi.org/10.18860/j-fsh.v12i2.7661

Available online at http://ejournal.uin-malang.ac.id/index.php/syariah

\title{
Sinkronisasi Regulasi tentang Hak Ekonomi Anak di Indonesia dengan Convention on The Rights of The Child \\ Synchronization of Regulations on Children's Economic Rights in Indonesia with the Convention on The Rights of The Child
}

\author{
Moh Usman \\ UIN Sunan Ampel Surabaya \\ usmanainurrafiq@gmail.com
}

Abstract:

Children are the next generation who must be given protection by parents, society and the state. Various regulations were formulated to ensure the fulfillment of children's rights. However, various regulations regarding the guarantee of children's rights often lead to legal disharmony. This article aims to describe the synchronization of regulations on the maintenance of the economic rights of children in the family, particularly with the Convention on The Rights of The Child. This article is derived from doctrinal legal research using statutory regulations and conceptual approaches. The results of this study indicate that the material contained in several laws in Indonesia is in line with the Convention on the Rights of the Child, such as the amount of material for children's economic maintenance rights. Even so, there are still regulations that are not synchronized, for example with regard to limits on children's economic maintenance and allowing parents to take children's assets.

Keywords: children's rights; family; regulation.

\section{Abstrak:}

Anak merupakan generasi penerus yang harus diberikan perlindungan oleh orang tua, masyarakat, dan negara. Berbagai regulasi dirumuskan untuk menjamin terpenuhinya hak-hak anak. Namun, berbagai regulasi tentang jaminan hak-hak anak tidak jarang menimbulkan disharmoni hukum. Artikel ini bertujuan mendeksripsikan sinkronisasi regulasi pemeliharaan hak ekonomi anak dalam keluarga, khususnya dengan Convention on The Rights of The Child. Artikel ini berasal dari penelitian hukum doktrinal dengan pendekaran peraturan perundang-undangan dan pendekatan konsep. Hasil dari penelitian ini menunjukkan bahwa materi yang terkandung dalam beberapa perundang-undangan di Indonesia sudah sejalan antara Konvensi Hak Anak, seperti besaran materi hak pemeliharaan ekonomi anak. Meskipun demikian, masih terdapat regulasi yang belum sinkron, misalnya berkaitan dengan batas pemeliharaan ekonomi anak dan diperbolehkannya orang tua mengambil harta anak.

Kata Kunci: hak anak; keluarga; undang-undang. 


\section{Pendahuluan}

Undang-undang No. 23 tahun 2002 yang telah diubah dengan Undang-undang No. 35 tahun 2014 tentang Perlindungan Anak Pasal 1 ayat 1: "Dalam Undangundang ini yang dimaksud dengan anak adalah seseorang yang belum berusia 18 tahun, termasuk anak yang masih dalam kandungan." Kemudian di dalam Undangundang No. 1 tahun 1974 tentang Perkawinan Pasal 47 ayat 1 menyebutkan bahwa: "Anak yang belum mencapai umur 18 (delapan belas) tahun atau belum pernah melangsungkan perkawinan ada di bawah kekuasaan orang tuanya selama mereka tidak dicabut dari kekuasaannya." Anak adalah keturuan manusia yang dilahirkan sebab adanya hubungan biologis antara laki-laki dan perempuan. ${ }^{1}$ Kartini Kartono mendefinisikan anak sebagai suatu keadaan manusia yang masih berusia muda, sangat labil jiwanya dan sedang menentukan identitasnya sehingga mudah terpengaruh oleh lingkungan sekitarnya. ${ }^{2}$ Sebagai bagian dari salah satu generasi muda dan penerus cita-cita bangsa, anak mempunyai ciri dan sifat khusus, sehingga memerlukan perlakuan, pembinaan dan perlindungan khusus agar pertumbuhan fisik, mental dan sosial mereka terjamin. ${ }^{3}$

Perlindungan anak merupakan kegiatan dalam melindungi dan menjamin hak anak agar dia dapat tumbuh dan berkembang secara optimal sesuai dengan nilai-nilai kemanusiaan. Perlindungan ini juga bermakna anak mendapat perlindungan dari kekerasan dan diskriminasi agar dia bisa menjadi pribadi yang berakhlak mulia di masa depan. ${ }^{4}$ Perlindungan anak mencakup semua aspek dalam kehidupan anak, baik dalam realisasi hak-haknya ataupun kewajibannya. Hukum perlindungan anak merupakan serangkaian hukum yang menjamin hak-hak dan kewajiban anak. Hukum tersebut dapat berupa hukum perdata, pidana, atau peraturan perundangundangan yang terkait. Ini ditunjukkan agar anak dapat benar-benar tumbuh sesuai dengan hak asasi yang melekat pada dirinya. ${ }^{5}$

Prinsip khusus mengenai perlindungan anak telah diatur dalam Pasal 2 Undang-undang No. 35 Tahun 2014 tentang perubahan atas Undang-undang No. 23 Tahun 2003 mengenai Perlindungan Anak dan sesuai dengan Prinsip-prinsip umum perlindungan anak dalam Convention on The Rights of The Child atau di Indonesia lebih dikenal dengan Konvensi Hak Anak (KHA), yakni: ${ }^{6}$ (1). Prinsip Nondiskriminasi; (2). Prinsip kepentingan terbaik bagi anak (Best Interest of The Child); (3). Prinsip hak hidup, kelangsungan hidup dan perkembangan (The Right to Life, Survival and development); (4). Prinsip Penghargaan terhadap pendapat anak (Respect for The Views of The Child). Prinsip ini merupakan prinsip paten yang

\footnotetext{
${ }^{1}$ Antarini Arna dan Adzkar Ahsinin, Advokasi Anggaran Berbasis Hak Anak; Langkah Demi Langkah (Jakarta: Yayasan Pemantau Hak Anak, 2007), 1.

${ }^{2}$ Abintoro Prakoso, Hukum Perlindungan Anak (Yogyakarta: Laksbang PressIndo, 2016), 36.

${ }^{3}$ Suryo Sakti Hadiwijoyo, Pengarusutamaan Hak Anak dalam Anggaran Publik (Yogyakarta: Graha Ilmu, 2015), 2.

${ }^{4}$ Anissa Nur Fitri, Agus Wahyudi Riana, dan Muhammad Fedryansyah, "Perlindungan Hak-Hak Anak Dalam Upaya Peningkatan Kesejahteraan Anak," Prosiding Penelitian dan Pengabdian kepada Masyarakat 2, no. 1 (1 September 2015), https://doi.org/10.24198/jppm.v2i1.13235.

${ }^{5}$ Maidin Gultom, Perlindungan hukum terhadap anak, dalam sistem peradilan pidana anak di Indonesia (Bandung: Refika Aditama, 2008), 32.

${ }^{6}$ Hadi Supeno, Kriminalisasi Anak Tawaran Gagasan Radikal Peradilan Anak Tanpa Pemidanaan (Jakarta: Gramedia Pustaka Utama, 2010), 41.
} 
harus direalisasikan dalam pemenuhan hak anak yang salah satunya adalah hak pemeliharaan ekonomi anak dalam keluarga.

Hukum positif di Indonesia mengatur bahwa kewajiban untuk memelihara hak ekonomi anak ialah bersifat memaksa (dwingendrecht). Artinya kewajiban tersebut tidak dapat gugur hanya dengan melakukan perjanjian atasnya. Orang tua sebagai orang yang berkewajiban untuk mengimpelentasikan hak tersebut wajib melakukan kewajbannya memenuhi hak anak sesuai kemampuannya. ${ }^{7}$ Hampir di semua peraturan perundang-undangan di Indonesia yang berbicara mengenai anak dan keluarga terdapat pembahasan mengenai hak anak, khususnya hak pemeliharaan ekonomi anak. Pada dasarnya, seluruh undang-undang tersebut mempunyai esensi yang sama, yakni kepentingan terbaik bagi anak. Sejalan dengan diratifikasinya KHA melalui Keputusan Presiden No. 36 Tahun 1990 tentang Pengesahan Konvensi Hak-Hak Anak, seharusnya peraturan perundang-undangan di Indonesia yang mempunyai relevansi mengenai hak anak harus disesuaikan agar terdapat harmoni hukum, khususnya yang berkaitan dengan hak pemeliharaan ekonomi anak dalam keluarga.

Semangat pembentukan suatu perundang-undangan sangat berpengaruh terhadap materi yang akan dimuat di dalamnya. Perbedaan periode, kepentingan politik dan dinamisme jaman dalam pembuatan peraturan perundang-undangan berakibat pada perbedaan konten dan subtansi. Setiap undang-undang mempunyai landasan filosofis, sosiologis dan ketentuan lain dalam setiap pasal yang dipaparkan. ${ }^{8}$ Secara teoritis ataupun praktis ini tentu akan berakibat pada penerapan hukum yang akan dilaksanakan di lapangan. Oleh sebab itu, salah satu tujuan dari kajian ini adalah untuk mengetahui sejauh mana sinkronisasi hukum di Indonesia baik secara vertikal ataupun horisontal, khususnya antara peraturan perundang-undangan di Indonesia dan Konvensi Hak Anak mengenai hak pemeliharaan ekonomi anak dalam keluarga.

Penelitian ini merupakan penelitian hukum doktriner atau dogmatis untuk menemukan pola sinkronisasi hukum dengan menggunakan data sekunder. ${ }^{9}$ Adapun pendekatan yang diterapkan dalam penelitian ini ialah memakai pendekatan peraturan perundang-undangan pada taraf sinkronisasi hukum. ${ }^{10}$ Sumber data yang digunakan adalah bahan hukum primer dan sekunder yang didapat dari peraturan perundang-undangan, beberapa buku dan jurnal. Bahan hukum yang didapat lalu diseleksi dan diklasifikasikan berdasarkan golongannya secara sistematis. Kemudian setelah data terkumpul dianalisa dengan analisis deskriptif kualitatif. Yang menjadi pokok utama dalam penelitian ini adalah analisis datanya memakai pola sinkronisasi hukum sehingga membentuk suatu kontruksi hukum khususnya dalam bidang hak pemeliharaan ekonomi anak dalam keluarga.

\section{Hasil dan Pembahasan}

\section{Hak Pemeliharaan Ekonomi Anak dalam Keluarga}

Hak menurut Philipus M. Hadjon adalah sesuatu yang tidak hanya dapat ditahbiskan dan dipahami secara ilahiyah (Divinely ordained and Divinely

\footnotetext{
${ }^{7}$ Rosnindar Sembiring, Hukum Keluarga, Harta-Harta Benda Dalam Perkawinan (Jakarta: Raja Grafindo Persada, 2016), 151.

${ }^{8}$ Maidin Gultom, Perlindungan hukum terhadap anak, dalam sistem peradilan pidana anak di Indonesia, 32.

${ }^{9}$ Soerjono Soekanto, Pengantar Penelitian Hukum (Jakarta: UI-Press, 1986), 51.

${ }^{10}$ Peter Mahmud Marzuki, Penelitian Hukum (Jakarta: Prenada Media Group, 2016), 133.
} 
conceived). Hak adalah anugerah dari pencipta sebagai konsekuensi manusia sebagai ciptaannya. Hak merupakan bawaan lahir yang kemudian dibawa ke dalam kehidupan bermasyarakat. ${ }^{11}$ Tidak hanya orang dewasa, anak juga mempunyai hak asasi yang harus diberikan dan dijaga. Karena isu dan pemberitaan yang ada tidak segencar hak asasi manusia (HAM) atau isu gender, maka tidak begitu banyak pihak yang memikirkan perlidungan anak secara aplikatif, praktis dan kongkrit. Hal ini yang kemudian menjadikan semaraknya pelanggaran hak anak, seperti anak jalanan, anak terlantar dan lain-lain. ${ }^{12}$

Padahal regulasi mengenai hak anak yang melekat sejak sebelum dia lahir tertera dalam konstitusi Negara Kesatuan Republik Indonesia. Undang-undang Dasar 1945 Pasal 28B ayat (2) menyebut: "Setiap anak berhak atas kelangsungan hidup, tumbuh kembang serta atas perlindungan dari kekerasan dan diskriminasi."

Dalam mukaddimah Konvensi Hak Anak dinyatakan bahwa "Anak karena ketidak mampuan Jasmani dan mentalnya, memerlukan pengamanan dan pemeliharaan khusus termasuk perlindungan hukum yang layak sebelum dan sesudah kelahiran". Adapun hak anak sebagaimana tertera di dalam Undang-undang mengenai Hak Asasi Manusia No. 39 Tahun 1999 ayat ke-2 adalah: "Hak anak adalah hak asasi manusia dan untuk kepentingannya, hak anak itu diakui dan dilindungi oleh hukum bahkan sejak dalam kandungan. ${ }^{13}$ Sedangkan di dalam ketentuan umum Undang-undang No. 35 tahun 2014 tentang perubahan atas Undang-undang No. 23 tahun 2002 tentang Perlindungan Anak dipaparkan bahwa hak anak adalah bagian dari hak asasi manusia yang wajib dijamin, dilindungi, dan dipenuhi oleh orang tua, keluarga, masyarakat, pemerintah, dan negara.

Convention on The Rights of The Child (Konvensi Hak-Hak Anak) Tahun 1989 sebagaimana yang telah diratifikasi melalui Keputusan Presiden No. 36 Tahun 1990 tentang Pengesahan Konvensi Hak-Hak Anak menyatakan bahwa hak-hak anak secara umum dibagi dalam 4 (empat) kategori, antara lain: (1). Hak untuk kelangsungan hidup (The Right to Survival); (2). Hak terhadap perlindungan (Protection Rights); (3). Hak untuk tumbuh kembang (Development Rights); (4). Hak untuk berpartisipasi (Paticipation Rights). Empat kategori ini merupakan dasar utama hak anak yang harus diberikan dan dijaga. ${ }^{14}$

Undang-undang No. 39 Tahun 1999 Tentang Hak Asasi Manusia Pasal 52 menjelaskan bahwa: "(1). Setiap anak berhak atas perlindungan oleh orang tua, keluarga, masyarakat, dan negara. (2). Hak anak adalah hak asasi manusia dan untuk kepentingannya hak anak itu diakui dan dilindungi oleh hukum bahkan sejak dalam kandungan." Pasal ini menekankan bahwa perlindungan terhadap anak sebagai implementasi hak yang harus diberikan terhadapnya yang paling utama ialah dibebankan kepada orang tua, baru kemudian lingkungan sekitarnya.

Secara subtansif Pasal tersebut juga mempunyai relevansi dengan Undangundang No. 1 Tahun 1974 tentang Perkawinan di Pasal 45: "(1). Kedua orang tua wajib memelihara dan menddidik anak-anak mereka sebaik-baiknya. (2). Kewajiban orang tua yang dimaksud dalam ayat (1) pasal ini berlaku sampai anak itu kawin atau dapat berdiri sendiri kewajiban mana berlaku terus meskipun perkawinan antara

\footnotetext{
${ }^{11}$ Mashur Efendi, Dimensi/Dinamika Hak Asasi Manusia dalam Hukum Nasional dan Internasional (Jakarta: Ghalia, 1994), 16.

${ }^{12}$ Suryo Sakti Hadiwijoyo, Pengarusutamaan Hak Anak dalam Anggaran Publik, 6.

${ }^{13}$ Candar Gautama, Kovensi Hak-Hak Anak, Panduan Bagi Jurnalis (Jakarta: LSPP, 2000), 21-22.

${ }^{14}$ Nasril Jamil, Anak bukan Untuk Dihukum (Jakarta: Sinar Grafika, 2015), 14-20.
} 
kedua orang tua putus." Kemudian di dalam pasal 47 ayat 1 di Undang-undang yang sama menyebutkan: "Anak yang belum mencapai umur 18 (delapan belas) tahun atau belum pernah melangsungkan perkawinan ada di bawah kekuasaan orang tuanya selama mereka tidak dicabut dari kekuasaannya." KHA sebagai instrumen internasional menekankan agar setiap negara pihak mengakui dan mengimplementasikan hak yang melekat dalam diri anak. Sebagaimana Pasal 6: "(1). States Parties recognize that every child has the inherent right to life. (2). States Parties shall ensure to the maximum extent possible the survival and development of the child."Di samping menuntut agar anak diberikan hak yang semestinya, KHA juga menekankan agar negara pihak menghormati hak dan kewajiban yang melekat pada orang tua anak, sebagaimana dalam Pasal 5: "States Parties shall respect the responsibilities, rights and duties of parents or, where applicable, the members of the extended family or community as provided for by local custom, legal guardians or other persons legally responsible for the child, to provide, in a manner consistent with the evolving capacities of the child, appropriate direction and guidance in the exercise by the child of the rights recognized in the present Convention."

Pengesahan konvensi hak anak pada 20 November 1989 seharusnya bisa mengikat negara yang telah meratifikasinya menjadi peraturan di negaranya masingmasing. Konvensi hak anak yang terdiri dari 54 bab dan telah melewati kajian matang itu seharusnya bisa diserap dan diintegrasikan ke dalam hukum positif masing-masing. ${ }^{15}$ Erna Sofyan Syukrie mengatakan bahwa negara yang telah meratifikasi KHA, seharusnya bisa melakukan harmoni hukum dengan: ${ }^{16}$ Pertama, Memeriksa dan melakukan analisa terhadap perundang-undangan yang ada dan masih dalam tahap perencanaan atau pembentukan. Kedua, melakukan peninjauan terhadap lembaga yang mempunyai relevansi dengan implementasi konvensi hak anak. Ketiga, mengusulkan langkah alternatif mengenai penyelarasan ketentuan konvensi hak anak. Keempat, melakukan peninjauan ulang terhadap perundangundangan yang berlaku namun masih memerlukan beberapa penyempurnaan dan impelementasi yang tepat. Kelima, melakukan penyelarasan konvensi hak anak dengan perundang-undangan di Indonesia.

Sedangkan Joni berpendapat bahwa konsekuensi praktis dari diratifikasinya KHA adalah penyelarasan hukum nasional yang dapat dilakukan dengan beberapa hal yakni: Pertama, memasukkan ketentuan mengenai hak anak dalam KHA ke dalam hukum positif nasional. Kedua, melakukan peninjauan kembali mengenai hukum positif yang tidak sesuai dengan KHA; Ketiga, mengidentifikasi adanya kemungkinan diperlukannya penyusunan perundang-undangan atau peraturan lain yang dapat membantu impelementasi KHA. ${ }^{17}$

\section{Sinkronisasi Hak Pemeliharaan Ekonomi Anak Dalam Hukum Positif Di Indonesia}

Semua hak anak dalam KHA pada dasarnya terkandung dalam empat hak umum anak dan prinsip perlindungan anak sebagaimana tersebut di atas. Regulasi dan pengaturan yang ada seyogyanya harus disesuaikan dengan dua hal tersebut. Namun ketentuan dalam KHA yang mengatur secara langsung mengenai hak anak

\footnotetext{
${ }^{15}$ Muhammad Joni dan Zulchaina Z. Tanamas, Aspek Hukum Perlindungan Anak dalam Perspektif Konvensi Hak Anak (Bandung, 1999), 3-4.

${ }^{16}$ Hadi Supeno, Kriminalisasi Anak Tawaran Gagasan Radikal Peradilan Anak Tanpa Pemidanaan, 39.

${ }^{17}$ Hadi Supeno, 40.
} 
dalam keluarga berada di Pasal 3, Pasal 5, Pasal 6, Pasal 9 dan Pasal 27. Berbeda dengan peraturan perundang-undangan di Indonesia yang menekankan hak anak pada pihak terkait, baik orang tua, masyarakat atau lembaga pemerintah. Diksi yang dipakai dalam KHA ditunjukkan kapada negara-negara pihak. Namun pada dasarnya, pasal-pasal tersebut juga mempunyai korelasi kuat dengan hak utama anak dan prinsip perlindungan anak.

Adapaun sinkronisasi perundang-undangan bisa dilakukan memakai dua cara: sinkronisasi vertikal dan sinkronisasi horisontal. Kedua cara ini mempunyai maksud yang sama, yakni menelaah lebih lanjut sinkron tidaknya peraturan perundangundangan yang satu dan yang lain. ${ }^{18} 19 \mathrm{KHA}$ sebagai aturan yang telah diratifikasi tentu sudah mempunyai kedudukan yang kuat di dalam hukum positif. Sinkronisasi yang akan dilakukan adalah sinkronisasi vertikal dan horisontal. Baik sinkronisasi antara KHA dan peraturan perundang-undangan di Indonesia ataupun peraturan perundang-undangan satu dengan yang lain yang sama-sama memiliki relevansi mengenai hak pemeliharaan ekonomi anak dalam keluarga. Pada dasarnya sinkronisasi yang akan dilakukan meliputi lima poin penting yakni: Besaran materi hak pemeliharaan ekonomi anak, batas pemeliharaan ekonomi anak dalam keluarga, hak ekonomi anak pasca cerai, penelantaran hak ekonomi anak dan mengambil harta anak. Mengenai hak pemeliharaan ekonomi anak dalam keluarga pun demikian, pada dasarnya ada lima poin penting yang akan penulis paparkan di bawah ini.

Adapun besaran materi mengenai hak pemeliharaan ekonomi anak pada dasarnya Undang-undang tidak menjabarkannya secara detail. Tetapi dalam Pasal 34 Undang-undang perkawinan dipaparkan: "(1). Suami wajib melindungi istrinya dan memberikan segala sesuatu keperluan hidup berumah tangga sesuai dengan kemampuannya. (2). Istri wajib mengatur urusan rumah-tangga sebaik-baiknya." Hukum positif di Indonesia pada dasarnya tidak mengatur secara rinci mengenai nominal besaran materi yang harus diberikan kepada anak. Seorang ayah wajib memberikan nafkah terhadap keluarganya, termasuk anaknya. Sedangkan ibunya mempunyai tanggungan untuk mengatur urusan rumah tangganya. Tidak ada ketentuan mengenai jumlah yang harus diberikan.

Mengenai besaran materi, KHA dalam Pasal 27 mengatakan bahwa pemeliharaan ekonomi anak merupakan tanggung jawab primer orang tua yang harus dilakukan untuk perkembangan anak. Sebagaimana dalam Pasal 27 ayat ke-2: "The parent(s) or others responsible for the child have the primary responsibility to secure, within their abilities and financial capacities, the conditions of living necessary for the child's development." KHA juga menekankan agar negara hadir dalam rangka membantu dalam hak pemeliharaan ekonomi anak, bahkan meskipun anak tersebut telah pindah keluar negeri, Pasal 27 ayat ke-4: "States Parties shall take all appropriate measures to secure the recovery of maintenance for the child from the parents or other persons having financial responsibility for the child, both within the State Party and from abroad. In particular, where the person having financial responsibility for the child lives in a State different from that of the child, States Parties shall promote the accession to international agreements or the conclusion of such agreements, as well as the making of other appropriate arrangements" Ini

\footnotetext{
${ }^{18} \mathrm{~K}$. Goesnadhie, Harmonisasi Hukum: Dalam Perspektif Peraturan Perundang- Undangan (Surabaya: JP Books, 2006), 23-24.

${ }^{19}$ Goesnadhie, K., Harmonisasi Hukum: Dalam PerspektifPeraturan Perundang- Undangan, (Surabaya: JP Books, 2006) $23-24$
} 
menunjukkan bahwa pada dasarnya semangat peraturan perundang-undangan di Indonesia, khususnya Undang-undang perkawinan memiliki semangat yang sama mengenai besaran materi yang harus diberikan. Prinsip utama yang dipakai adalah kepentingan terbaik bagi anak (Best interest of the child) dan hak untuk kelangsungan hidup (The Right to Survival). Namun KHA sebagai regulasi internasional menekankan agar negara lebih hadir dalam permasalahan tersebut semata-mata demi perkembangan anak.

\section{Batas pemeliharaan ekonomi anak dalam keluarga}

Memelihara hak ekonomi anak merupakan kewajiban orang tua yang melekat sejak anak belum lahir, sesuai dengan Undang Hak Asasi Manusia No. 39 Tahun 1999 Pasal 52 ayat ke-2. Hukum positif di Indonesia juga mengatur mengenai batasan usia anak dimana orang tua sudah dinyatakan tidak mempunyai tanggung jawab lagi untuk memelihara hak ekonominya. Materi tersebut tercantum di dalam Pasal 45 Undang-undang No. 1 Tahun 1974 tentang Perkawinan: "(1). Kedua orang tua wajib memelihara dan menddidik anak-anak mereka sebaik-baiknya (2). Kewajiban orang tua yang dimaksud dalam ayat (1) Pasal ini berlaku sampai anak itu kawin atau dapat berdiri sendiri, kewajiban mana berlaku terus meskipun perkawinan antara kedua orang tua putus." Muatan pasal tersebut tidak secara eksplisit menyebut batas usia anak yang sudah dinyatakan mandiri dan orang tua sudah tidak perlu lagi memberikan hak pemeliharaan ekonomi. Namun materi tersebut mempunyai relevansi dengan Pasal selanjutnya yakni di Pasal 47: "(1). Anak yang belum mencapai umur 18 (delapan belas) tahun atau belum pernah melangsungkan perkawinan ada di bawah kekuasaan orang tuanya selama mereka tidak dicabut dari kekuasaannya. (2). Orang tua mewakili anak tersebut mengenai segala perbuatan hukum di dalam dan di luar Pengadilan."

Ini berarti bahwa anak yang sudah berusia 18 tahun atau belum kawin tetap berada di bawah tanggungan orang tuanya. Ketentuan pasal ini tidak menyebut secara langsung batas maksimal dimana seorang anak dikatakan dapat berdiri sendiri dan bebas dari tanggungan orang tuanya, namun apabila dipahami melalui interpretasi a contario, 18 tahun merupakan batas usia dimana anak dikatakan dapat beridri sendiri berdasar Undang-undang perkawinan. Agaknya ketentuan tersebut berbeda dengan materi yang terkandung dalam Pasal 98 Kompilasi Hukum Islam (KHI) yakni: "(1). Batas usia anak yang mampu berdiri sendiri atau dewasa adalah 21 tahun, sepanjang anak tersebut tidak bercacat fisik maupun mental atau belum pernah melangsungkan perkawinan. (2). Orang tuanya mewakili anak tersebut mengenai segala perbuatan hukum di dalam dan di luar Pengadilan. (3). Pengadilan Agama dapat menunjuk salah seorang kerabat terdekat yang mampu menunaikan kewajiban tersebut apabila kedua orang tuanya tidak mampu." Pasal tersebut mengatakan bahwa batasan anak sudah dapat dikatakan dewasa dan berdiri sendiri adalah saat dia berumur 21 tahun selama dia tidak cacat fisik dan belum pernah kawin. Sedangkan anak yang berumur lebih dari 21 tahun, apabila mengalami cacat fisik atau mental, maka masih berada dalam pengawasan orang tuanya. Ketentuan pasal dalam KHI ini sejalan dengan Undang-undang Nomor 4 tahun 1979 tentang Kesejahteraan Anak Pasal 1 ayat (2) yang mengatur bahwa devinisi anak adalah mereka yang berumur ke bawah 21 tahun dan belum menikah. ${ }^{20}$

\footnotetext{
${ }^{20}$ Rosnindar Sembiring, Hukum Keluarga, Harta-Harta Benda Dalam Perkawinan, 152.
} 
Dari penjelasan di atas, terdapat ketidak sesesuaian aturan hukum secara horisontal antara Pasal 47 Undang-undang perkawinan, Pasal 1 Undang-undang Kesejahteraan Anak dan perbedaan aturan secara vertikal yakni Pasal 47 Undangundang perkawinan dan KHI Pasal 98 mengenai batasan anak yang dapat dikatan berdiri sendiri. Sebagai aturan dengan status intruksi Presiden, secara herarkis, KHI berada di bawah Undang-undang perkawinan. Namun kedudukan KHI sebagai lex specialis dalam hal ini tentu harus diperhatikan. Sedangkan dalam KHA tidak menjelaskan secara detail mengenai batasan dimana orang tua sudah tidak mempunyai tanggung jawab pemeliharaan ekonomi terhadap anak, namun Pasal 6 KHA menjelaskan bahwa negara harus menjamin sampai pada jangkauan semaksimal mungkin mengenai ketahanan dan perkembangan anak. Sebagaimana bunyi pasalnya: (1). States Parties recognize that every child has the inherent right to life. (2). States Parties shall ensure to the maximum extent possible the survival and development of the child.

\section{Pemeliharaan Ekonomi Anak Pasca Perceraian}

Dalam Undang-undang No.1 tahun 1974 tentang perkawinan Pasal 41 disebutkan: "Akibat putusnya perkawinan karena perceraian ialah: (a). Baik ibu atau bapak tetap berkewajiban memelihara dan mendidik anak-anaknya semata mata berdasarkan kepentingan anak, bilamana ada perselisihan mengenai penguasaan anak, Pengadilan memberi keputusan. (b). Bapak yang bertanggung jawab atas semua biaya pemeliharaan dan pendidikan yang diperlukan anak itu, bilamana bapak dalam kenyataannya tidak dapat memberi kewajiban tersebut, Pengadilan dapat menentukan bahwa ibu ikut memikul biaya tersebut. (c). Pengadilan dapat mewajibkan kepada bekas suami untuk memberikan biaya penghidupan dan/atau menentukan sesuatu kewajiban bagi bekas isteri."

Pasal di atas tidak menyebut batasan umur kapan seorang anak harus diasuh oleh ayahnya atau pun ibunya, ketentuan poin (a) hanya mengatakan bahwa Pengadilan akan memberi keputusan bila terjadi perselisihan. Sedangkan di dalam KHI Pasal 105 menyebutkan: (a). Pemeliharaan anak yang belum mumayyiz atau belum berumur 12 tahun adalah hak ibunya; (b). Pemeliharaan anak yang sudah mumayyiz diserahkan kepada anak untuk memilih diantara ayah atau ibunya sebagai pemegang hak pemeliharaanya; (c). Biaya pemeliharaan ditanggung oleh ayahnya." KHI menjelaskan patokan usia dimana seorang anak harus berada di bawah kekuasaan ibunya adalah ketika dia belum memasuki usia 12 tahun. Sedangkan yang sudah berumur 12 tahun diberikan hak memilih kepada anak. Adapun biaya tetap berada di bawah tanggungan ayah. Perbedaan yang mencolok antara KHI dan Undang-undang Perkawinan adalah mengenai batasan mumayyiz dimana anak diberikan hak memilih dan juga tidak ada ketentuan mengenai tanggung jawab ibu sebagai pengganti ayahnya apabila ayahnya tidak mampu. Meskipun dalam implementasinya tidak ada problem, untuk menghindari multi tafsir di kemudian hari, seharusnya kedua perundang-undangan tersebut bisa diselaraskan.

Adapun di dalam Kitab Undang-undang Hukum Perdata (KUH Per) hal tersebut tertera dalam Pasal 229 yakni: "Setelah memutuskan perceraian, dan setelah mendengar atau memanggil dengan sah para orang tua atau keluarga sedarah atau semenda dan anak-anak yang di bawah umur, Pengadilan Negeri akan menetapkan siapa dari kedua orang tua akan melakukan perwalian atas tiap-tiap anak, kecuali 
jika kedua orang tua itu dipecat atau dilepaskan dan kekuasaan orang tua, dengan mengindahkan putusan-putusan Hakim terdahulu yang mungkin memecat atau melepas mereka dan kekuasaan orang tua. Penetapan ini tidak berlaku sebelum hari putusan perceraian perkawinan itu memperoleh kekuatan hukum yang pasti. Sebelum itu tidak usah dilakukan pemberitahuan, dan tidak boleh dilakukan perlawanan atau banding."

Dalam KUH Per yang berhak menentukan bahwa seorang anak akan menjadi tanngung jawab siapa setelah bercerai murni wewenang Pengadilan Negeri. Pengadilan Negeri akan mempertimbangkan kemudian memutus siapa yang lebih berwenang untuk bertanggung jawab terhadap anak. Sebagaimana diatur dalam Undang-undang tersebut, pemberian hak ekonomi anak setelah perceraian antara kedua orang tuanya ialah wajib, khususnya pihak ayah. Namun apabila kemampuan ayah untuk melakukan hal tersebut tidak memungkinkan, maka kewajiban juga diberikan kepada pihak ibu. Tujuan utama dari kewajiabn tersebut adalah agar anak tidak terlantar akibat perceraian ayah dan ibunya. Namun di sini, sesuai dengan KHA, pihak Pengadilan juga harus proaktif agar putusan mengenai pemberian hak ekonomi anak benar-benar terlaksana. ${ }^{21}$

Sedangkan dalam Konvensi Hak Anak (KHA) Pasal 9 menyatakan: (1). States Parties shall ensure that a child shall not be separated from his or her parents against their will, except when competent authorities subject to judicial review determine, in accordance with applicable law and procedures, that such separation is necessary for the best interests of the child. Such determination may be necessary in a particular case such as one involving abuse or neglect of the child by the parents, or one where the parents are living separately and a decision must be made as to the child's place of residence. (2). In any proceedings pursuant to paragraph 1 of the present article, all interested parties shall be given an opportunity to participate in the proceedings and make their views known.

Dalam KHA orang tua harus dilibatkan sepenuhnya oleh Pengadilan dalam proses memilih siapa yang lebih berhak terhadap pemeliharaan anak. Sedangkan di dalam KHI, sebagaimana dalam Pasal 105, apabila dia belum berumur 12 tahun atau belum mumayyiz, dia akan diasuh oleh ibunya. Apabila dia sudah berumur 12 tahun, dia diberikan hak memilih. Sedangkan dalam KUH Per, Hakim memegang peranan untuk menentukan semuanya. Terdapat perbedaan subtansi antara ketentuan dalam KHA dan KHI. KHA menekankan supaya orang tuanya dilibatkan dalam keadaan apapun agar dapat memberikan pendapatnya di depan Pengadilan, sedangkan dalam KHI, anak akan diberi pilihan untuk memilih hanya ketika sudah di atas usia 12 tahun. Secara subtansial, ketentuan dalam KHI memiliki maksud yang sama dengan ayat (1) Pasal $9 \mathrm{KHA}$, yakni agar anak tidak dipisahkan dari orang tuanya yang bertentangan dengan kemauan mereka.

Adapun besaran pemeliharaan ekonomi anak bagi orang tua non ASN ialah tergantung keputusan Hakim yang dipertimbangkan dengan kemampuan orang tuanya. Biasanya akan dinegosiasikan bersama para hakim dan orang tua saat sidang untuk kemudian dimuat di putusan. Untuk besaran biaya pemeliharaan ekonomi anak pasca cerai, Undang-undang tidak mengatur hal tersebut. Pada dasarnya ketentuan normatif dalam perundang-undangan menyiratkan suatu pedoman yang

\footnotetext{
${ }^{21}$ Nur Cholifah \&amp Bambang Ali Kusumo, "Hak Nafkah Anak Akibat Perceraian," Jurnal Wacana Hukum 10, no. 2 (2011): 63, https://doi.org/10.33061/1.jwh.2011.10.2.255.
} 
wajib dilakukan oleh Hakim dalam mengkaji dan memutus nominal hak ekonomi anak setelah orang tuanya bercerai. Pedoman tersebut adalah ukuran kelayakan, kepatutan dan keadila bagi ayah dan anaknya. ${ }^{22}$ Kemudian apabila suami tidak membayar berdasar yang termuat dalam putusan, istri berhak mengajukan gugatan eksekusi atas tunjangan hak asuh anak yang tidak dibayar oleh suami kepada Pengadilan. Untuk ASN, sebagaimana di dalam Pasal 8 Peraturan Pemerintah (PP) No. 10 Tahun 1983 jo. PP No. 45 Tahun 1990 tentang Izin Perkawinan dan Perceraian menyebut bahwa mantan suami wajib menyerahkan sebagian gajinya untuk bekas istri dan anak-anaknya. Besarnya adalah 1/3 untuk PNS pria, 1/3 untuk bekas istrinya dan 1/3 untuk anak-anaknya. Apabila melangggar akan dikenakan sanksi disiplin berat. Adapun dalam KHA, semua akan diputuskan di Pengadilan yang dihadiri semua pihak yang berkepentingan.

\section{Penelantaran Hak Ekonomi Anak}

Anak terlantar adalah anak yang tidak terpelihara, tidak terurus karena sebab tertentu, sehingga kebutuhan jasmani dan perkembangan kepribadiannya tidak terpenuhi. Salah satu penyebabnya adalah tidak diberikannya hak pemeliharaan ekonominya dalam keluarga. ${ }^{23}$ Ancaman terhadap orang tua yang lalai dalam melaksanakan kewajibannya untuk memenuhi hak pemeliharaan ekonomi anak tercantum dalam Pasal 9 Undang-undang No. 23 Tahun 2004 tentang Penghapusan Kekerasan dalam Rumah Tangga: "(1). Setiap orang dilarang menelantarkan orang dalam lingkup rumah tangganya, padahal menurut hukum yang berlaku baginya atau karena persetujuan atau perjanjian ia wajib memberikan kehidupan, perawatan, atau pemeliharaan kepada orang tersebut. (2). Penelantaran sebagaimana dimaksud pada ayat (1) juga berlaku bagi setiap orang yang mengakibatkan ketergantungan ekonomi dengan cara membatasi dan/atau melarang untuk bekerja yang layak di dalam atau di luar rumah sehingga korban berada di bawah kendali orang tersebut."

Pasal di atas mempunyai relevansi dengan pasal 49 yang berbunyi "Dipidana dengan pidana penjara paling lama 3 (tiga) tahun atau denda paling banyak Rp 15.000.000,00 (lima belas juta rupiah), setiap orang yang: a. menelantarkan orang lain dalam lingkup rumah tangganya sebagaimana dimaksud dalam Pasal 9 ayat (1); b. menelantarkan orang lain sebagaimana dimaksud dalam Pasal 9 ayat (2). Kemudian diatur juga di dalam Pasal 76B Undang-undang No. 35 tentang Perlindungan Anak: "Setiap Orang dilarang menempatkan, membiarkan, melibatkan, menyuruh, melibatkan Anak dalam situasi perlakuan salah dan penelantaran." Dilanjutkan dengan Pasal 77B "Setiap Orang yang melanggar ketentuan sebagaimana dimaksud dalam Pasal 76B, dipidana dengan pidana penjara paling lama 5 (lima) tahun dan/atau denda paling banyak Rp100.000.000,00 (seratus juta rupiah)."

Undang-undang No. 23 tahun 2002 yang telah dirubah dengan Undangundang No. 35 tahun 2014 tentang perlindungan anak Pasal 77 juga mengatur, yakni: "Setiap orang yang dengan sengaja melakukan tindakan: (a). diskriminasi terhadap anak yang mengakibatkan anak mengalami kerugian, baik materil maupun moril sehingga menghambat fungsi sosialnya; atau (b). penelantaran terhadap anak

\footnotetext{
${ }^{22}$ M. Natsir Asnawi, "Implementasi Jurimetri Dalam Penentuan Jumlah Nafkah Anak," Jurnal Hukum Dan Peradilan 5, no. 3 (30 November 2016): 341, https://doi.org/10.25216/jhp.5.3.2016.331-350.

${ }^{23}$ Fitri, Riana, dan Fedryansyah, "Perlindungan Hak-Hak Anak Dalam Upaya Peningkatan Kesejahteraan Anak," 48.
} 
yang mengakibatkan anak mengalami sakit atau penderitaan, baik fisik, mental, maupun sosial, dipidana dengan pidana penjara paling lama 5 (lima) tahun dan/atau denda paling banyak Rp 100.000.000,00 (seratus juta rupiah). "Pada dasarnya setiap Undang-undang di atas mempunyai semangat yang sama, yakni memberantas penelantaran anak dalam keluarga. Meskipun ketentuan sanksi hukum bagi penelantar anak terjadi perbedaan, namun semangat yang ada dapat dikatakan sesuai dengan Pasal 3 KHA, yakni: "(1). In all actions concerning children, whether undertaken by public or private social welfare institutions, courts of law, administrative authorities or legislative bodies, the best interests of the child shall be a primary consideration. (2). States Parties undertake to ensure the child such protection and care as is necessary for his or her well-being, taking into account the rights and duties of his or her parents, legal guardians, or other individuals legally responsible for him or her, and, to this end, shall take all appropriate legislative and administrative measures." Dalam pasal tersebut, KHA menekankan bahwa segala tindakan mengenai anak oleh lembaga atau instusi negara, baik yang berkaitan dengan kesejahteraan sosial atau hukum semua harus didasarkan pada kepentingan terbaik anak.

\section{Mengambil Harta Anak}

Di samping mengenai pemenuhan hak ekonomi anak, pearturan perundangundangan di Indonesia juga mengatur mengenai kewajiban orang tua dalam mengatur, menjaga dan merawat bahkan mengambil harta anaknya sebagaimana Pasal 106 KHI: "(1). Orang tua berkewajiban merawat dan mengembangkan harta anaknya yang belum dewasa atau di bawah pengampunan, dan tidak diperbolehkan memindahkan atau menggadaikannya kecuali karena keperluan yang mendesak jika kepentingan dan keselamatan anak itu menghendaki atau suatu kenyataan yang tidak dapat dihindarkan lagi. (2). Orang tua bertanggung jawab atas kerugian yang ditimbulkan karena kesalahan dan kelalaian dari kewajiban tersebut pada ayat (1)."

Adapun dalam Pasal 48 Undang-undang Perkawinan menyebutkan: "Orang tua tidak diperbolehkan memindahkan hak atau menggandakan barang-barang tetap yang dimiliki anaknya yang belum berumur 18 (delapan belas) tahun atau belum pernah melangsungkan perkawinan, kecuali apabila kepentingan anak itu menghendakinya". Pasal 311 KUH Per menyebutkan: "Bapak atau ibu yang melakukan kekuasaan orang tua atau perwalian, berhak menikmati hasil dan barangbarang anak-anaknya yang belum dewasa. Dalam hal orang tua itu, baik bapak maupun ibu, dilepaskan dari kekuasaan orang tua atau perwalian, kedua orang tua itu berhak untuk menikmati hasil dan kekayaan anak anak mereka yang masih di bawah umur. Pembebasan bapak atau ibu yang melakukan kekuasaan orang tua atau perwalian, sedang orang tua yang lainnya telah meninggal atau dibebaskan atau dipecat dan kekuasaan orang tua atau perwalian tidak berakibat terhadap hak menikmati hasil." Kemudian dilanjutkan: "Dengan hak menikmati hasil itu, terkait kewajiban-kewajiban: (1). hal-hal yang diwajibkan bagi pemegang hak pakai hasil. (2). pemeliharaan dan pendidikan anak-anak itu, sesuai dengan harta kekayaan mereka yang disebut terakhir; (3). pembayaran semua angsuran dan bunga atas uang pokok; (4). biaya penguburan anak.

Pasal di atas juga diperjelas dengan Pasal 313 yakni: "Hak menikmati hasil tidak terjadi: (1). terhadap barang-barang yang diperoleh anak-anak itu sendiri dari pekerjaan dan usaha sendiri: (2). terhadap barang-barang yang dihibahkan dengan 
akta semasa pewaris masih hidup atau dihibahkan dengan wasiat kepada mereka, dengan persyaratan tegas, bahwa kedua orang tua mereka tidak berhak menikmati hasilnya." Dan diteruskan dengan Pasal 314 yang berbunyi: "Hak menikmati hasil terhenti dengan kematian anak-anak itu". Terdapat perbedaan yang cukup kentara antara KHI, Undang-undang Perkawinan dan KUH Per. Dalam KHI orang tua berkewajiban untuk mengembangkan harta anak dan tidak diperbolehkan untuk menyalahgunakannya, kecuali dalam keadaan mendesak. Bahkan orang tua wajib mengganti harta tersebut apabila dalam proses pengembangan ternyata terjadi kerugian. Secara subtansial hal tersebut memiliki kesamaan dengan materi di dalam Undang-undang Perkawinan, namun yang membedakannya adalah tidak adanya diksi "mendesak" dalam Undang-undang perkawinan. Ini artinya apabila dipahami secara literal, Undang-undang Perkawinan memperbolehkan orang tua mempergunakan harta anaknya asalkan didasarkan pada kepentingan anak, walau tanpa kepentingan yang mendesak bagi anak. Sedangkan dalam KUH Per orang tua diberikan kewenangan untuk menikmati harta anaknya dengan syarat-syarat sebagaimana disebutkan. Mengenai pengambilan harta anak oleh orang tua KHA tidak memberikan penjelasan secara khusus. Namun sesuai dengan prinsip perlindungan anak, seharusnya orang tua tidak mempergunakan hak anaknya kecuali memang untuk kebutuhan masa dapan anak. Sehingga ketentuan ini sangat sesuai dengan yang di dalam KHI. Adapun dalam KUH Per dan Undang-undang Perkawinan, tentu terdapat perbedaan.

\section{Kesimpulan}

Dari beberapa uraian yang telah disampaikan, penulis mengambil kesimpulan bahwa beberapa peraturan perundang-undangan di Indonesia yang berkaitan dengan hak pemeliharaan ekonomi anak dalam keluarga pada dasarnya telah sejalan dengan semangat dan prinsip yang terkandung dalam convention of the righ of the child, kecuali pada bidang dimana orang tua diperbolehkan mengambil harta anak dalam keadaan tidak mendesak. Beberapa peraturan perundang-undang juga memiliki perbedaan materi antar satu dengan yang lain, seperti mengenai batas pemeliharaan hak ekonomi anak dalam KHI dan Undang-undang Perkawinan, hak memilih terhadap anak pasca orang tuanya bercerai di KHI, Undang-undang perkawinan dan Kitab Undang-undang Hukum Perdata. Perbedaan tersebut meskipun secara praktis ada pada taraf yang berbeda, seharusnya tidak boleh meninggalkan hak utama dan prinsip perlindungan anak sebagaimana tercantum dalam KHA.

\section{Daftar Pustaka}

Abintoro Prakoso. Hukum Perlindungan Anak. Yogyakarta: Laksbang PressIndo, 2016. Antarini Arna dan Adzkar Ahsinin. Advokasi Anggaran Berbasis Hak Anak; Langkah Demi Langkah. Jakarta: Yayasan Pemantau Hak Anak, 2007.

Asnawi, M. Natsir. "Implementasi Jurimetri Dalam Penentuan Jumlah Nafkah Anak." Jurnal Hukum Dan Peradilan 5, no. 3 (30 November 2016): 331-50. https://doi.org/10.25216/jhp.5.3.2016.331-350.

Bambang Ali Kusumo, Nur Cholifah \&amp. "Hak Nafkah Anak Akibat Perceraian." Jurnal Wacana Hukum 10, no. 2 (2011): 23494. https://doi.org/10.33061/1.jwh.2011.10.2.255.

Candar Gautama. Kovensi Hak-Hak Anak, Panduan Bagi Jurnalis. Jakarta: LSPP, 2000. 
Fitri, Anissa Nur, Agus Wahyudi Riana, dan Muhammad Fedryansyah. "Perlindungan Hak-Hak Anak Dalam Upaya Peningkatan Kesejahteraan Anak." Prosiding Penelitian dan Pengabdian kepada Masyarakat 2, no. 1 (1 September 2015). https://doi.org/10.24198/jppm.v2i1.13235.

Hadi Supeno. Kriminalisasi Anak Tawaran Gagasan Radikal Peradilan Anak Tanpa Pemidanaan. Jakarta: Gramedia Pustaka Utama, 2010.

K. Goesnadhie. Harmonisasi Hukum: Dalam Perspektif Peraturan Perundang- Undangan. Surabaya: JP Books, 2006.

Maidin Gultom. Perlindungan hukum terhadap anak, dalam sistem peradilan pidana anak di Indonesia. Bandung: Refika Aditama, 2008.

Mashur Efendi. Dimensi/Dinamika Hak Asasi Manusia dalam Hukum Nasional dan Internasional. Jakarta: Ghalia, 1994.

Muhammad Joni dan Zulchaina Z. Tanamas. Aspek Hukum Perlindungan Anak dalam Perspektif Konvensi Hak Anak. Bandung, 1999.

Nasril Jamil. Anak bukan Untuk Dihukum. Jakarta: Sinar Grafika, 2015.

Peter Mahmud Marzuki. Penelitian Hukum. Jakarta: Prenada Media Group, 2016.

Rosnindar Sembiring. Hukum Keluarga, Harta-Harta Benda Dalam Perkawinan. Jakarta: Raja Grafindo Persada, 2016.

Soerjono Soekanto. Pengantar Penelitian Hukum. Jakarta: UI-Press, 1986.

Suryo Sakti Hadiwijoyo. Pengarusutamaan Hak Anak dalam Anggaran Publik. Yogyakarta: Graha Ilmu, 2015. 